\title{
Awareness of Knowledge Management in Nepalese Financial Institutions
}

\author{
Lekhanath Khanal \\ PhD Scholar, Mewar University, Rajasthan, India
}

\begin{abstract}
Knowledge Management (KM) is one of the buzzwords prevailing in the management circles. It is seen as a tool which can create a strategic impact. Organizations which are unaware of knowledge management (KM) and its concepts are considered illiterate in business context. In order to thrive in this turbulent market, an organization must be familiar with all concepts pertaining to its intellectual assets, i.e. Knowledge, and all other activities involved in managing its intangible assets, i.e. KM through various practices, suitable strategy and processes,. Banks and financial institutions as drivers of economic growth play a major role in prosperity and innovativeness of almost all countries worldwide. The main objective of this study is to identify the awareness of knowledge management in financial institutions of Nepal. In this study, samples of 385 respondents were selected randomly from four different types of financial institutions of Kathmandu, Nepal. The statistical analysis was done to draw the conclusion. The results clearly show that the level of KM awareness amongst Nepalese financial institutions is medium in which some companies understand the principles of KM but they observe many challenges and difficulties in pursuing KM implementation. Finally, this paper concludes that those institutions which are aware of the basic concepts and principle of KM can effectively manage knowledge resources; are more innovative and have better performance than others who do not takes this factor into account
\end{abstract}

Keywords: Awareness, Banking \& Finance, Knowledge management

\section{INTRODUCTION}

In a highly demanding business world today, an organization's competitive edge almost wholly depends on how well it can manage and deploy its corporate assets. These assets can be categorized into tangible and intangible assets. Traditionally, tangible assets like plant, equipment, inventory and financial capital are considered the most fundamental corporate assets. Intangible assets play a very little or vague role in any organization regardless from which industry it comes from (Vorbeck, Heisig, Martin \& Schutt, 2001). Generally, many organizations until today still downplay the importance of their intangible assets. However, despite managing and giving prime focus to all their tangible assets, organizations are still finding it very hard to gain the advantage to beat their competitors. Eventually, organizations have found out that tangible assets can only help them to a certain extent. It is now becoming clearer that organizations require a much broader range of resources to be able to compete and succeed in the current competitive market. This is shown by an increasing number of organizations giving more emphasis to their intangible assets, which was mostly left idle, unexplored and unmanaged (Vorbeck et al., 2001).

To compete and become successful in their own market, organizations must now learn to manage their intangible asset, that is "Knowledge" and this practice is generally known as Knowledge Management or sometimes is referred to as business intelligence. Knowledge management is the concept in which an enterprise consciously and comprehensively gathers, organizes, shares, and analyzes its knowledge in term of resources, documents, and people's skills (Lyons, 2000). The emergence of this "knowledge era" is radically changing what creates value in organizations (Carlisle, 2002), whereby the long-term viability and 
prosperity of an organization increasingly depends on its ability to leverage the hidden value of its intangible assets.

Therefore, knowledge management is now becoming an undeniably important component in an organization's intangible asset. The continuous change in market expectations and the demands for new products have been gradually replacing the capital and labor-intensive firms by knowledge intensive firms, and routine work by knowledge worker.

For the past 25 years, financial institutions have been actively automating their manual processes. This has resulted in the creation of many information systems even within one organization. While these information systems were able to help them to better manage their processes and resources, they also have created a number of setbacks. One major setback of past information system is that it has resulted in the creation of huge volumes of data and information, resulting in a phenomenon like information explosion or information overload. This phenomenon occurs when we are faced with overwhelming amount of information, and we have to take time to go through the bulk of information and select the best one to use. When there is the load of information it could result in less reactive responses and decline of capacity. With huge amount of information being created consistently, inefficiency occurs. Consequently, efficient and effective recovery of resource and knowledge has increasingly becoming an imminent research issue in recent times.

Without proper management information systems, plans, procedures and tools, information has become a very serious and annoying problem in many organizations to the extent that most of the time information is regarded as noise. Nevertheless, realizing the important roles they play in the economy, companies are trying to make it a priority to capture and manage their data and turn it into organizational knowledge or business intelligence. However, the lack of process definition, classification, a comprehensive knowledge management model, and suitable knowledge based business model make the efforts futile in the last decade.

Even though the utilization of knowledge has become a key factor for the success of organizations, management has found it difficult to transform their firm through programs of knowledge management. Many models and theoretical frameworks from various perspectives try to explain knowledge management, but empirical proof of knowledge related hypotheses are scarce; also there is a lack of coherence between different concepts of knowledge management. For practicing managers, there is a major gap between knowledge management theory and practice. It is therefore essential to gain a clear and comprehensive understanding of how knowledge works within the organization. Hence, research is needed to build a comprehensive model of the context of knowledge management strategy and more so how it applies to financial organizations in the developing world. Although knowledge management has been widely discussed by many academicians and practitioners, there is paucity of literature and information on knowledge management in Nepalese context. This research has examined knowledge management awareness and practices of financial institutions in Nepal and by doing so it contributes towards the difficult problem of using knowledge management processes within a given context. Therefore, the major objective of the study is to identify the level of awareness of Knowledge Management in Nepalese financial institutions.

\section{RESEARCH METHOD}

The study is based on the quantitative research design. The data was collected from the banking and financial institutions of Kathmandu, Nepal by using the structured questionnaire survey. In total, 385 respondents were selected from the financial institutions by using the proportionate stratified random sampling technique. The questionnaire was developed in five-level Likert Scale as (1) Strongly disagree, (2) Disagree, (3) Neutral, (4) Agree and (5) Strongly agree. The research instrument was pre-tested to ensure the validity and reliability of data. The collected data was analyzed through the statistical models: frequency, mean and Chi-Square test. The data is presented in the tabular form. 


\section{RESULTS}

Table 1 describes the types of respondents of Nepalese banking and financial institutions participated in this study. Respondents are categorized based on four sectors including Government Banks (20\%), Private Commercial Banks (40\%), Development Banks (20\%), and Finance and Cooperatives (20\%). 64.4\% male and $35.6 \%$ of female of various designation/job title from Chief Executive Officer to Clerical Staff were selected using stratified sampling method. Among them 21 respondents are high school graduates, 103 respondents hold bachelor's degree, 255 respondents hold master's degree and remaining 6 respondents got MPHIL/PHD. Respondents with experience of less than six months were discarded and minimum six months to maximum 46 years were taken for analysis being mean years of experience 10.324 with standard deviation 7.87 years.

\section{Gender distribution of respondents}

Table-1: Gender of Respondents

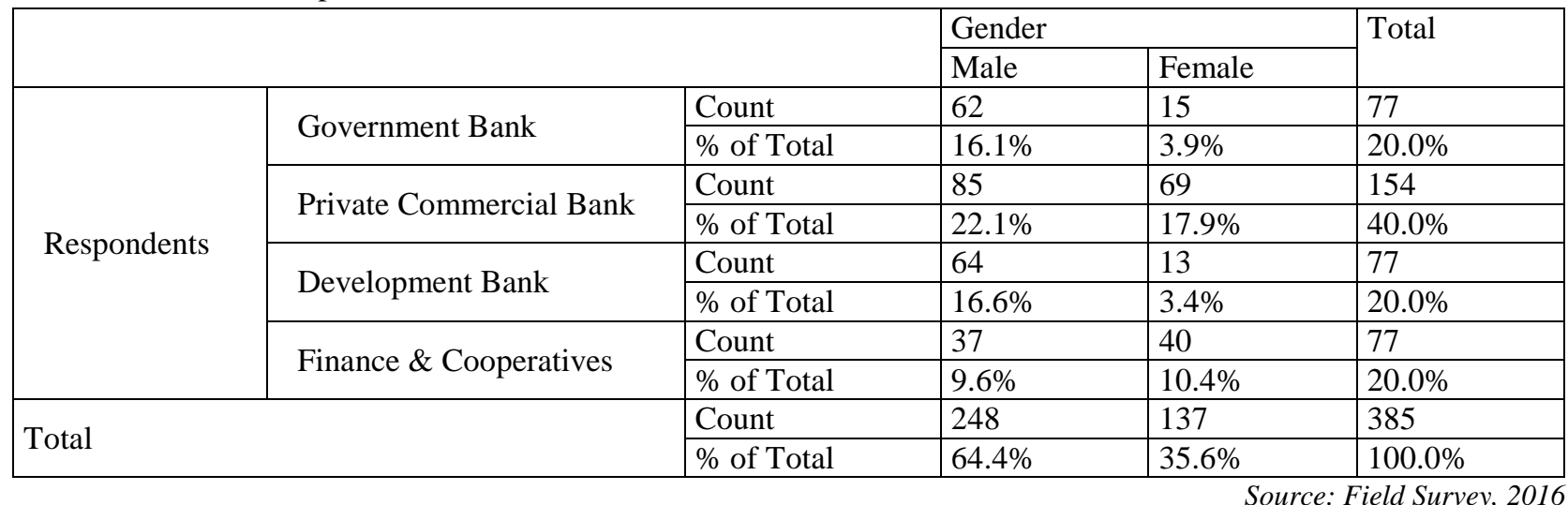

Regarding number of staffs working under the respondents, $39.0 \%$ have below 10 employees; $31.1 \%$ have employees between 10 and 20; 15.4\% have employees between 20 and 30; 5.9\% have employees between 30 and 40; 3.5\% have employees between 40 and 60 and remaining $5.1 \%$ have employees above 60 . From the date of establishment, it is found that $40.5 \%$ of organizations have been in business for 5 to 10 years, $35.9 \%$ for 10 to 30 years and $23.6 \%$ of them have more than 30 years of experience.

In Nepalese context, financial sector, especially banking and finance companies are very competitive. Knowledge is resource to gain competitive advantage in this sector. Obtaining comprehensive information on how knowledge is managed and utilized is very important. Awareness of KM in terms of terminology and its key components are found imminent for manager and other employees in these organizations. In the following sections, the result of questions pertaining to Nepalese financial institutions' understanding and perceptions toward KM have been analyzed and categorized in terms of statements asked in questionnaire:

\section{KM is a process of creation, assimilation, retention and utilization of knowledge}

The respondents' degree of agreement/disagreement toward this statement is summarized in table 2 . Surprisingly, most respondents decided to concur with the first statement in which 53.5 percent have chosen "agree" and 29.4 percent for "strongly agree". 11.9 percent have chosen "neutral". It can be deduced that all the participants have chosen correctly regarding this statement.

Table-2: KM is a process of creation, assimilation, retention and utilization of knowledge 


\begin{tabular}{|c|c|c|c|c|c|c|c|c|}
\hline & \multicolumn{5}{|c|}{$\begin{array}{l}\text { KM is a process of creation, assimilation, retention } \\
\text { and utilization of knowledge }\end{array}$} & \multirow[t]{2}{*}{ Total } \\
\hline & & & $\begin{array}{l}\text { Strongly } \\
\text { Disagree }\end{array}$ & Disagree & Neutral & Agree & $\begin{array}{l}\text { Strongly } \\
\text { Agree }\end{array}$ & \\
\hline \multirow{8}{*}{ Respondents } & \multirow{2}{*}{ Government Bank } & Count & 1 & 2 & 5 & 39 & 30 & 77 \\
\hline & & $\%$ of Total & $0.3 \%$ & $0.5 \%$ & $1.3 \%$ & $10.1 \%$ & $7.8 \%$ & $20.0 \%$ \\
\hline & \multirow{2}{*}{ Commercial Bank } & Count & 4 & 7 & 28 & 81 & 34 & 154 \\
\hline & & $\%$ of Total & $1.0 \%$ & $1.8 \%$ & $7.3 \%$ & $21.0 \%$ & $8.8 \%$ & $40.0 \%$ \\
\hline & \multirow{2}{*}{ Development Bank } & Count & 0 & 2 & 9 & 53 & 13 & 77 \\
\hline & & $\%$ of Total & $0.0 \%$ & $0.5 \%$ & $2.3 \%$ & $13.8 \%$ & $3.4 \%$ & $20.0 \%$ \\
\hline & \multirow{2}{*}{ Finance \& Cooperatives } & Count & 2 & 2 & 4 & 33 & 36 & 77 \\
\hline & & $\%$ of Total & $0.5 \%$ & $0.5 \%$ & $1.0 \%$ & $8.6 \%$ & $9.4 \%$ & $20.0 \%$ \\
\hline \multirow{2}{*}{\multicolumn{2}{|c|}{ Total }} & Count & 7 & 13 & 46 & 206 & 113 & 385 \\
\hline & & $\%$ of Total & $1.8 \%$ & $3.4 \%$ & $11.9 \%$ & $53.5 \%$ & $29.4 \%$ & $100.0 \%$ \\
\hline \multicolumn{9}{|c|}{ Chi-Square Tests } \\
\hline \multirow{2}{*}{\multicolumn{2}{|c|}{ Pearson Chi-Square }} & \multicolumn{2}{|l|}{ Value } & \multicolumn{2}{|l|}{ Df } & \multicolumn{3}{|c|}{ Asymp. Sig. (2-sided) } \\
\hline & & $35.568^{\mathrm{a}}$ & & 12 & & .000 & & \\
\hline
\end{tabular}

The statistical analysis of Chi-Square test found the significant association among the four different financial institutions regarding the response on $\mathrm{KM}$ is a process of creating knowledge because the $\mathrm{P}=.000$ which is less than .05 significant level.

3. KM is the management of information, knowledge and experience accessible to a company

Surprisingly, as tabulated in table 3, most respondents (49.6 percent have chosen "agree" and 30.1 percent have chosen "strongly agree") agreed with this statement which is precisely what knowledge management is about in order to obtain a competitive advantage. Very few respondents disagreed and some of them (16.6 percent) chose "neutral".

Table-3: KM is the management of information, knowledge and experience accessible to a company

\begin{tabular}{|c|c|c|c|c|c|c|c|c|}
\hline & \multicolumn{5}{|c|}{$\begin{array}{l}\mathrm{KM} \text { is the management of information, knowledge } \\
\text { and experience accessible to a company }\end{array}$} & \multirow[t]{2}{*}{ Total } \\
\hline & & & $\begin{array}{l}\text { Strongly } \\
\text { Disagree }\end{array}$ & Disagree & Neutral & Agree & \begin{tabular}{|l|} 
Strongly \\
Agree
\end{tabular} & \\
\hline \multirow{8}{*}{ Respondents } & \multirow{2}{*}{ Government Bank } & Count & 0 & 1 & 16 & 38 & 22 & 77 \\
\hline & & $\%$ of Total & $0.0 \%$ & $0.3 \%$ & $4.2 \%$ & $9.9 \%$ & $5.7 \%$ & $20.0 \%$ \\
\hline & \multirow{2}{*}{ Commercial Bank } & Count & 2 & 5 & 28 & 75 & 44 & 154 \\
\hline & & $\%$ of Total & $0.5 \%$ & $1.3 \%$ & $7.3 \%$ & $19.5 \%$ & $11.4 \%$ & $40.0 \%$ \\
\hline & \multirow{2}{*}{ Development Bank } & Count & 0 & 4 & 18 & 41 & 14 & 77 \\
\hline & & $\%$ of Total & $0.0 \%$ & $1.0 \%$ & $4.7 \%$ & $10.6 \%$ & $3.6 \%$ & $20.0 \%$ \\
\hline & \multirow{2}{*}{\begin{tabular}{|l} 
Finance \\
Cooperatives
\end{tabular}} & Count & 0 & 2 & 2 & 37 & 36 & 77 \\
\hline & & $\%$ of Total & $0.0 \%$ & $0.5 \%$ & $0.5 \%$ & $9.6 \%$ & $9.4 \%$ & $20.0 \%$ \\
\hline \multirow{2}{*}{\multicolumn{2}{|c|}{ Total }} & Count & 2 & 12 & 64 & 191 & 116 & 385 \\
\hline & & $\%$ of Total & $0.5 \%$ & $3.1 \%$ & $16.6 \%$ & $49.6 \%$ & $30.1 \%$ & $100.0 \%$ \\
\hline \multicolumn{9}{|c|}{ Chi-Square Tests } \\
\hline \multirow{2}{*}{\multicolumn{2}{|c|}{ Pearson Chi-Square }} & \multicolumn{2}{|l|}{ Value } & \multicolumn{2}{|l|}{$\mathrm{df}$} & \multicolumn{3}{|c|}{ Asymp. Sig. (2-sided) } \\
\hline & & $28.375^{\mathrm{a}}$ & & 12 & & .005 & & \\
\hline
\end{tabular}


The statistical analysis of Chi-Square test found the significant association among the four different financial institutions regarding the response on $\mathrm{KM}$ is the management of information, knowledge and experience accessible to a company because the $\mathrm{P}=.005$ which is less than .05 significant level.

4. KM is something already doing but not under the same name

Table 4: KM is something already doing but not under the same name

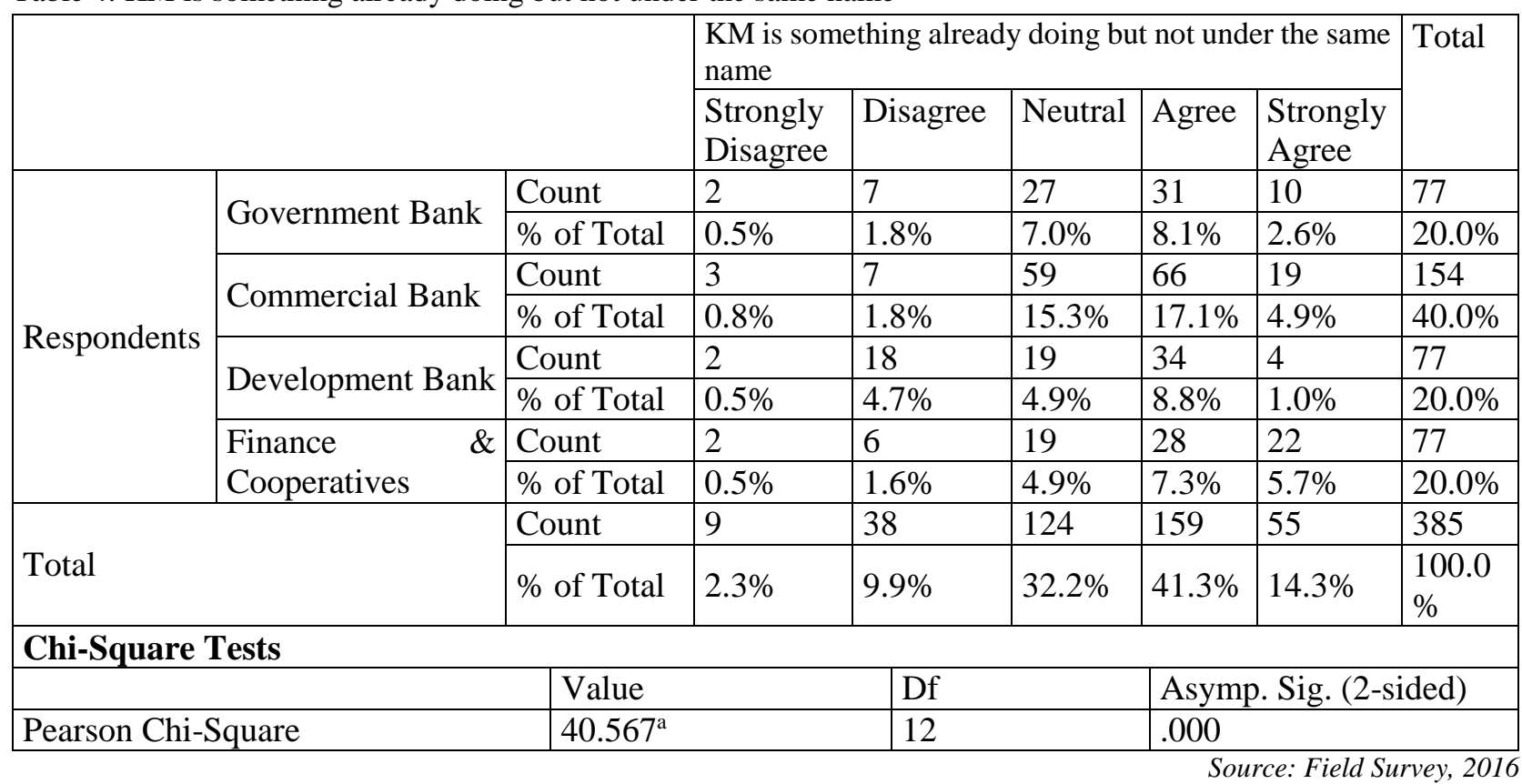

As shown in table-4, many of the respondents are neutral (32.2 percent) to this statement that KM is already practicing but under different name. This shows that the respondents are not clear whether their various knowledge initiatives fall under knowledge management or not. However most of the respondents are in line with this statement (41.3 percent "agree" \& 14.3 percent "strongly agree") and small portion of respondents are against this statement ( 9.9 percent "disagree" \& only 2.3 percent "strongly disagree").

The statistical analysis of Chi-Square test found the significant association among the four different financial institutions regarding the response on $\mathrm{KM}$ is something already doing but not under the same name because the $\mathrm{P}$ $=.000$ which is less than .05 significant level.

\section{KM is a theory developed by an academician}

Again, as shown in table 5, many of the respondents (36.6 percent) have chosen "neutral" and remaining majority (33 percent "agree" \& 13.2 percent "strongly agree") are in accord to this statement while minority of the respondents (14 percent "disagree" \& only 3.1 percent "strongly disagree") are in opposition to it.

Table-5: KM is a theory developed by an academician

\begin{tabular}{|l|l|l|l|l|l|l|l|l|}
\hline \multicolumn{2}{|c|}{} & & \multicolumn{3}{|l|}{ KM is a theory developed by an academician } & Total \\
\cline { 3 - 8 } & & $\begin{array}{l}\text { Strongly } \\
\text { Disagree }\end{array}$ & Disagree & Neutral & Agree & $\begin{array}{l}\text { Strongly } \\
\text { Agree }\end{array}$ & \\
\hline Respondents & Government Bank & Count & 0 & 14 & 29 & 25 & 9 & 77 \\
\hline
\end{tabular}


ISSN: 2362-1303 (Paper) | elSSN: 2362-1311(Online)

JOURNAL OF ADVANCED ACADEMIC RESEARCH (JAAR)

October 2016

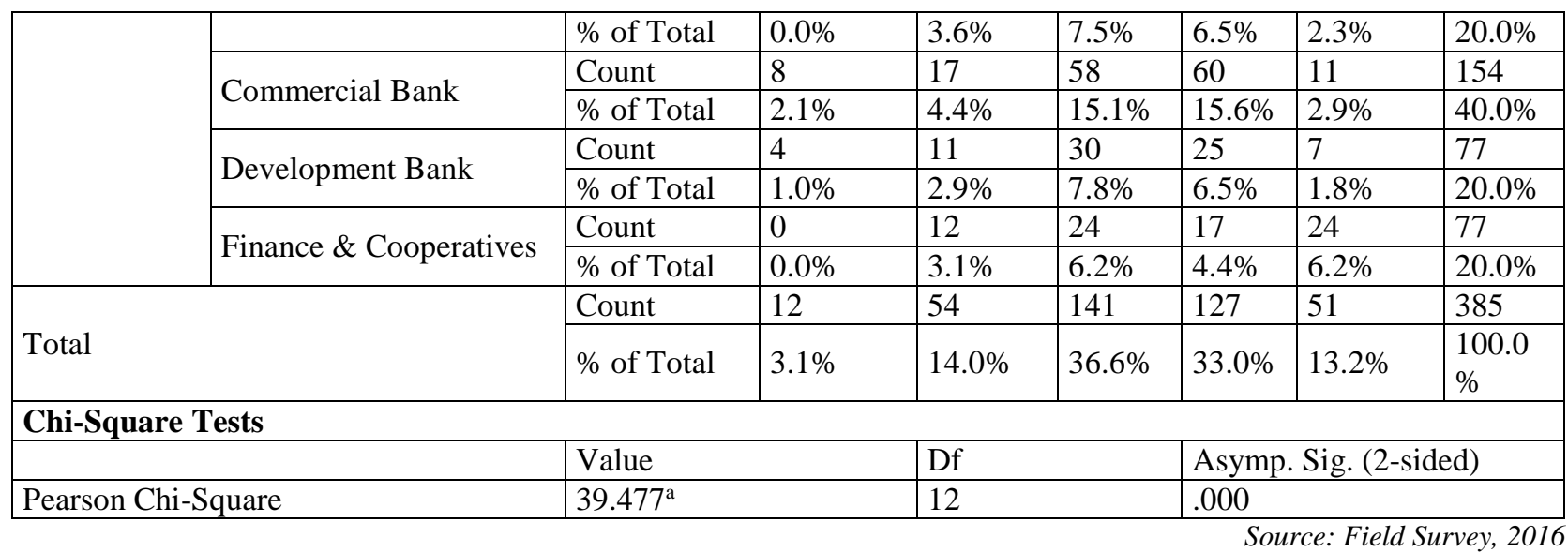

The statistical analysis of Chi-Square test found the significant association among the four different financial institutions regarding the response on KM is a theory developed by an academicianbecause the $\mathrm{P}=.000$ which is less than .05 significant level.

6. KM is strategic part of the business

Table-6: KM is strategic part of the business

\begin{tabular}{|c|c|c|c|c|c|c|c|c|}
\hline & \multicolumn{5}{|c|}{$\mathrm{KM}$ is strategic part of the business } & \multirow[t]{2}{*}{ Total } \\
\hline & & & $\begin{array}{l}\text { Strongly } \\
\text { Disagree }\end{array}$ & Disagree & Neutral & Agree & $\begin{array}{l}\text { Strongly } \\
\text { Agree }\end{array}$ & \\
\hline \multirow{8}{*}{ Respondents } & \multirow{2}{*}{ Government Bank } & Count & 1 & 3 & 8 & 48 & 17 & 77 \\
\hline & & $\%$ of Total & $0.3 \%$ & $0.8 \%$ & $2.1 \%$ & $12.5 \%$ & $4.4 \%$ & $20.0 \%$ \\
\hline & \multirow{2}{*}{ Commercial Bank } & Count & 0 & 3 & 53 & 63 & 35 & 154 \\
\hline & & $\%$ of Total & $0.0 \%$ & $0.8 \%$ & $13.8 \%$ & $16.4 \%$ & $9.1 \%$ & $40.0 \%$ \\
\hline & \multirow{2}{*}{ Development Bank } & Count & 0 & 2 & 16 & 45 & 14 & 77 \\
\hline & & $\%$ of Total & $0.0 \%$ & $0.5 \%$ & $4.2 \%$ & $11.7 \%$ & $3.6 \%$ & $20.0 \%$ \\
\hline & \multirow{2}{*}{$\begin{array}{l}\text { Finance } \\
\text { Cooperatives }\end{array}$} & Count & 0 & 2 & 8 & 37 & 30 & 77 \\
\hline & & $\%$ of Total & $0.0 \%$ & $0.5 \%$ & $2.1 \%$ & $9.6 \%$ & $7.8 \%$ & $20.0 \%$ \\
\hline \multirow{2}{*}{\multicolumn{2}{|c|}{ Total }} & Count & 1 & 10 & 85 & 193 & 96 & 385 \\
\hline & & $\%$ of Total & $0.3 \%$ & $2.6 \%$ & $22.1 \%$ & $50.1 \%$ & $24.9 \%$ & $100.0 \%$ \\
\hline \multicolumn{9}{|c|}{ Chi-Square Tests } \\
\hline & & \multicolumn{2}{|l|}{ Value } & \multicolumn{2}{|l|}{$d f$} & \multicolumn{3}{|c|}{ Asymp. Sig. (2-sided) } \\
\hline \multicolumn{2}{|c|}{ Pearson Chi-Square } & \multicolumn{2}{|l|}{$39.021^{\mathrm{a}}$} & \multicolumn{2}{|l|}{12} & \multicolumn{2}{|c|}{.000} & \\
\hline
\end{tabular}

Surprisingly, as tabulated in table-6, most respondents (75 percent) agreed with this statement. 22.1 percent of respondents had to say nothing against this statement and the rest 2.9 percent firmly rejected that knowledge management is strategic part of business.

The statistical analysis of Chi-Square test found the significant association among the four different financial institutions regarding the response on KM is strategic part of the business because the $\mathrm{P}=.000$ which is less than .05 significant level. 
7. Knowledge Management is a new marketing strategy

As shown in table 7, some respondents (41.6 percent have chosen "agree" and 24.7 have chosen "strongly agree") agreed with this statement. Moreover, 10.4 percent (7.3 percent "disagree", 3.1 percent "strongly disagree") disagreed with this statement and remaining 23.4 percent of respondents remained neutral to this statement.

Table-7: Knowledge Management is a new marketing strategy

\begin{tabular}{|c|c|c|c|c|c|c|c|c|}
\hline & \multicolumn{5}{|c|}{$\begin{array}{l}\text { Knowledge Management is a new marketing } \\
\text { strategy }\end{array}$} & \multirow[t]{2}{*}{ Total } \\
\hline & & & $\begin{array}{l}\text { Strongly } \\
\text { Disagree }\end{array}$ & Disagree & Neutral & Agree & $\begin{array}{l}\text { Strongly } \\
\text { Agree }\end{array}$ & \\
\hline \multirow{8}{*}{ Respondents } & \multirow{2}{*}{ Government Bank } & Count & 4 & 8 & 13 & 34 & 18 & 77 \\
\hline & & $\%$ of Total & $1.0 \%$ & $2.1 \%$ & $3.4 \%$ & $8.8 \%$ & $4.7 \%$ & $20.0 \%$ \\
\hline & \multirow{2}{*}{ Commercial Bank } & Count & 1 & 14 & 59 & 43 & 37 & 154 \\
\hline & & $\%$ of Total & $0.3 \%$ & $3.6 \%$ & $15.3 \%$ & $11.2 \%$ & $9.6 \%$ & $40.0 \%$ \\
\hline & \multirow{2}{*}{ Development Bank } & Count & 0 & 4 & 12 & 43 & 18 & 77 \\
\hline & & $\%$ of Total & $0.0 \%$ & $1.0 \%$ & $3.1 \%$ & $11.2 \%$ & $4.7 \%$ & $20.0 \%$ \\
\hline & \multirow{2}{*}{ Finance \& Cooperatives } & Count & 7 & 2 & 6 & 40 & 22 & 77 \\
\hline & & $\%$ of Total & $1.8 \%$ & $0.5 \%$ & $1.6 \%$ & $10.4 \%$ & $5.7 \%$ & $20.0 \%$ \\
\hline \multirow{2}{*}{\multicolumn{2}{|c|}{ Total }} & Count & 12 & 28 & 90 & 160 & 95 & 385 \\
\hline & & $\%$ of Total & $3.1 \%$ & $7.3 \%$ & $23.4 \%$ & $41.6 \%$ & $24.7 \%$ & $\begin{array}{l}100.0 \\
\%\end{array}$ \\
\hline \multicolumn{9}{|c|}{ Chi-Square Tests } \\
\hline \multirow{2}{*}{\multicolumn{2}{|c|}{ Pearson Chi-Square }} & \multicolumn{2}{|l|}{ Value } & \multicolumn{2}{|l|}{$\mathrm{df}$} & \multicolumn{3}{|c|}{ Asymp. Sig. (2-sided) } \\
\hline & & $59.277^{\mathrm{a}}$ & & 12 & & .000 & & \\
\hline
\end{tabular}

The statistical analysis of Chi-Square test found the significant association among the four different financial institutions regarding the response on Knowledge Management is a new marketing strategybecause the $\mathrm{P}=.000$ which is less than .05 significant level.

\section{KM is something that could be beneficial for the organization}

Table-8: KM is something that could be beneficial for the organization

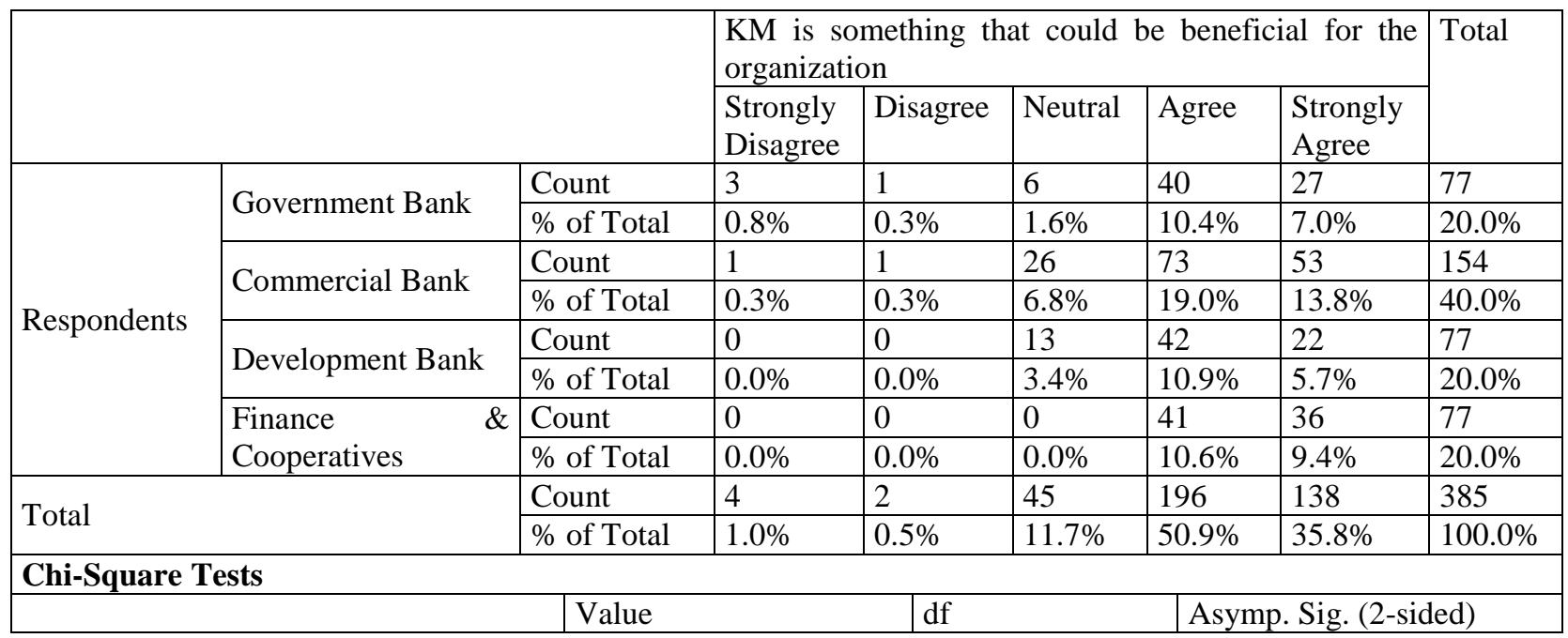


ISSN: 2362-1303 (Paper) | elSSN: 2362-1311(Online)

JOURNAL OF ADVANCED ACADEMIC RESEARCH (JAAR)

October 2016

Pearson Chi-Square

$29.423^{\mathrm{a}}$

12

.003

Source: Field Survey, 2016

Unsurprisingly, as illustrated in table 8, very large numbers of respondents ( 86.7 percent) have consented with this statement by choosing "agree/strongly agree") agreed with this statement with a view that KM is beneficial to the organization while minimal of respondents (1.5 percent) disagreed with this statement.

The statistical analysis of Chi-Square test found the significant association among the four different financial institutions regarding the response on KM is something that could be beneficial for the organization because the $\mathrm{P}$ $=.003$ which is less than .05 significant level.

9. KM is a type of process-improvement method

Table-9: KM is a type of process-improvement method

\begin{tabular}{|c|c|c|c|c|c|c|c|c|}
\hline & \multicolumn{5}{|c|}{ KM is a type of process-improvement method } & \multirow[t]{2}{*}{ Total } \\
\hline & & & $\begin{array}{l}\text { Strongly } \\
\text { Disagree }\end{array}$ & Disagree & Neutral & Agree & \begin{tabular}{|l} 
Strongly \\
Agree
\end{tabular} & \\
\hline \multirow{8}{*}{ Respondents } & \multirow{2}{*}{ Government Bank } & Count & 2 & 6 & 13 & 35 & 21 & 77 \\
\hline & & $\%$ of Total & $0.5 \%$ & $1.6 \%$ & $3.4 \%$ & $9.1 \%$ & $5.5 \%$ & $20.0 \%$ \\
\hline & \multirow{2}{*}{ Commercial Bank } & Count & 0 & 7 & 36 & 86 & 25 & 154 \\
\hline & & $\%$ of Total & $0.0 \%$ & $1.8 \%$ & $9.4 \%$ & $22.3 \%$ & $6.5 \%$ & $40.0 \%$ \\
\hline & \multirow{2}{*}{ Development Bank } & Count & 4 & 0 & 20 & 38 & 15 & 77 \\
\hline & & $\%$ of Total & $1.0 \%$ & $0.0 \%$ & $5.2 \%$ & $9.9 \%$ & $3.9 \%$ & $20.0 \%$ \\
\hline & \multirow{2}{*}{$\begin{array}{l}\text { Finance } \\
\text { Cooperatives }\end{array}$} & Count & 0 & 4 & 18 & 29 & 26 & 77 \\
\hline & & $\%$ of Total & $0.0 \%$ & $1.0 \%$ & $4.7 \%$ & $7.5 \%$ & $6.8 \%$ & $20.0 \%$ \\
\hline \multirow{2}{*}{\multicolumn{2}{|c|}{ Total }} & Count & 6 & 17 & 87 & 188 & 87 & 385 \\
\hline & & $\%$ of Total & $1.6 \%$ & $4.4 \%$ & $22.6 \%$ & $48.8 \%$ & $22.6 \%$ & $100.0 \%$ \\
\hline \multicolumn{9}{|c|}{ Chi-Square Tests } \\
\hline \multirow{2}{*}{\multicolumn{2}{|c|}{ Pearson Chi-Square }} & \multicolumn{2}{|l|}{ Value } & \multicolumn{2}{|l|}{ df } & \multicolumn{3}{|c|}{ Asymp. Sig. (2-sided) } \\
\hline & & \multicolumn{2}{|l|}{$29.518^{\mathrm{a}}$} & \multicolumn{2}{|l|}{12} & \multicolumn{3}{|c|}{.003} \\
\hline
\end{tabular}

Unsurprisingly, as illustrated in table 9, most of the respondents (71.4 percent) have consented with this statement by choosing "agree/strongly agree" but only 6 percent of the respondents disagreed with this statement. The weight of agreement is inclined towards private commercial banks as they are covering 28.8 percent alone for the statement of KM is a type of process-improvement method.

The statistical analysis of Chi-Square test found the significant association among the four different financial institutions regarding the response on KM is a type of process-improvement method because the $\mathrm{P}=.003$ which is less than .05 significant level.

\section{KM is a training program that all managers must participate}

As illustrated in table 10, a large number, i.e. 67 percent of the respondents ( 33.5 percent have chosen "agree" and 33.5 have chosen "strongly agree") agreed with this statement. Moreover, 21.6 percent are neutral and remaining 11.5 percent (9.4 percent "disagree" and 2.1 percent "strongly disagree") disagreed with this statement. This result establishes the perceived correlation between KM and training programs and also emphasizes the need of KM training in financial organizations.

Table-10: $\mathrm{KM}$ is a training program that all managers must participate 


\begin{tabular}{|c|c|c|c|c|c|c|c|c|}
\hline & \multicolumn{5}{|c|}{$\begin{array}{l}\mathrm{KM} \text { is a training program that all managers must } \\
\text { participate }\end{array}$} & \multirow[t]{2}{*}{ Total } \\
\hline & & & $\begin{array}{l}\text { Strongly } \\
\text { Disagree }\end{array}$ & Disagree & Neutral & Agree & $\begin{array}{l}\text { Strongly } \\
\text { Agree }\end{array}$ & \\
\hline \multirow{8}{*}{ Respondents } & \multirow{2}{*}{ Government Bank } & Count & 3 & 5 & 15 & 24 & 30 & 77 \\
\hline & & $\%$ of Total & $0.8 \%$ & $1.3 \%$ & $3.9 \%$ & $6.2 \%$ & $7.8 \%$ & $20.0 \%$ \\
\hline & \multirow{2}{*}{ Commercial Bank } & Count & 1 & 11 & 40 & 56 & 46 & 154 \\
\hline & & $\%$ of Total & $0.3 \%$ & $2.9 \%$ & $10.4 \%$ & $14.5 \%$ & $11.9 \%$ & $40.0 \%$ \\
\hline & \multirow{2}{*}{ Development Bank } & Count & 2 & 10 & 23 & 21 & 21 & 77 \\
\hline & & $\%$ of Total & $0.5 \%$ & $2.6 \%$ & $6.0 \%$ & $5.5 \%$ & $5.5 \%$ & $20.0 \%$ \\
\hline & \multirow{2}{*}{$\begin{array}{l}\text { Finance } \\
\text { Cooperatives }\end{array}$} & Count & 2 & 10 & 5 & 28 & 32 & 77 \\
\hline & & $\%$ of Total & $0.5 \%$ & $2.6 \%$ & $1.3 \%$ & $7.3 \%$ & $8.3 \%$ & $20.0 \%$ \\
\hline \multirow{2}{*}{\multicolumn{2}{|c|}{ Total }} & Count & 8 & 36 & 83 & 129 & 129 & 385 \\
\hline & & $\%$ of Total & $2.1 \%$ & $9.4 \%$ & $21.6 \%$ & $33.5 \%$ & $33.5 \%$ & $100.0 \%$ \\
\hline \multicolumn{9}{|c|}{ Chi-Square Tests } \\
\hline \multirow{2}{*}{\multicolumn{2}{|c|}{ Pearson Chi-Square }} & \multicolumn{2}{|l|}{ Value } & \multirow{2}{*}{\multicolumn{2}{|c|}{$\begin{array}{l}\mathrm{df} \\
12\end{array}$}} & \multicolumn{3}{|c|}{ Asymp. Sig. (2-sided) } \\
\hline & & $23.967^{\circ}$ & & & & & \\
\hline
\end{tabular}

Source: Field Survey, 2016

The statistical analysis of Chi-Square test found the significant association among the four different financial institutions regarding the response on KM is a training program that all managers must participate because the $\mathrm{P}=$ .021 which is less than .05 significant level.

\section{Knowledge Management is all about the utilization of ICT}

Table 11: Knowledge Management is all about the utilization of ICT

\begin{tabular}{|c|c|c|c|c|c|c|c|c|}
\hline & & & \multicolumn{5}{|c|}{$\begin{array}{l}\text { Knowledge Management is all about the utilization of } \\
\text { ICT }\end{array}$} & \multirow[t]{2}{*}{ Total } \\
\hline & & & $\begin{array}{l}\text { Strongly } \\
\text { Disagree }\end{array}$ & Disagree & Neutral & Agree & $\begin{array}{l}\text { Strongly } \\
\text { Agree }\end{array}$ & \\
\hline \multirow{8}{*}{ Respondents } & \multirow{2}{*}{ Government Bank } & Count & 1 & 5 & 25 & 37 & 9 & 77 \\
\hline & & $\%$ of Total & $0.3 \%$ & $1.3 \%$ & $6.5 \%$ & $9.6 \%$ & $2.3 \%$ & $20.0 \%$ \\
\hline & \multirow{2}{*}{ Commercial Bank } & Count & 4 & 14 & 68 & 55 & 13 & 154 \\
\hline & & $\%$ of Total & $1.0 \%$ & $3.6 \%$ & $17.7 \%$ & $14.3 \%$ & $3.4 \%$ & $40.0 \%$ \\
\hline & \multirow{2}{*}{ Development Bank } & Count & 2 & 12 & 33 & 26 & 4 & 77 \\
\hline & & $\%$ of Total & $0.5 \%$ & $3.1 \%$ & $8.6 \%$ & $6.8 \%$ & $1.0 \%$ & $20.0 \%$ \\
\hline & \multirow{2}{*}{$\begin{array}{ll}\text { Finance } \& \\
\text { Cooperatives }\end{array}$} & Count & 8 & 10 & 25 & 24 & 10 & 77 \\
\hline & & $\%$ of Total & $2.1 \%$ & $2.6 \%$ & $6.5 \%$ & $6.2 \%$ & $2.6 \%$ & $20.0 \%$ \\
\hline \multirow{2}{*}{\multicolumn{2}{|c|}{ Total }} & Count & 15 & 41 & 151 & 142 & 36 & 385 \\
\hline & & $\%$ of Total & $3.9 \%$ & $10.6 \%$ & $39.2 \%$ & $36.9 \%$ & $9.4 \%$ & $100.0 \%$ \\
\hline \multicolumn{9}{|c|}{ Chi-Square Tests } \\
\hline & & \multicolumn{2}{|l|}{\begin{tabular}{|l|} 
Value \\
\end{tabular}} & \multicolumn{2}{|l|}{ df } & \multicolumn{3}{|c|}{ Asymp. Sig. (2-sided) } \\
\hline \multicolumn{2}{|c|}{ Pearson Chi-Square } & $24.072^{\mathrm{a}}$ & & \multicolumn{2}{|l|}{12} & \multicolumn{2}{|c|}{.020} & \\
\hline
\end{tabular}

As illustrated in table 11, some of the respondents (36.9 percent have chosen "agree" and 9.4 percent have chosen "strongly agree") agreed with this statement. Moreover, 14.5 percent of respondents (10.6 percent "disagree" and 3.9 percent "strongly disagree") are not in line with this, and significant number of respondents (39.2 percent) has chosen neither "Agree" nor "Disagree". 
The statistical analysis of Chi-Square test found the significant association among the four different financial institutions regarding the response on Knowledge Management is all about the utilization of ICT because the $\mathrm{P}=$ .020 which is less than .05 significant level.

\section{KM is nothing but a management trend or fad}

Table 12: KM is nothing but a management trend or fad

\begin{tabular}{|c|c|c|c|c|c|c|c|c|}
\hline & \multicolumn{5}{|c|}{$\mathrm{KM}$ is nothing but a management trend or fad } & \multirow[t]{2}{*}{ Total } \\
\hline & & & $\begin{array}{l}\text { Strongly } \\
\text { Disagree }\end{array}$ & Disagree & Neutral & Agree & $\begin{array}{l}\text { Strongly } \\
\text { Agree }\end{array}$ & \\
\hline \multirow{8}{*}{ Respondents } & \multirow{2}{*}{ Government Bank } & Count & 6 & 16 & 24 & 27 & 4 & 77 \\
\hline & & $\%$ of Total & $1.6 \%$ & $4.2 \%$ & $6.2 \%$ & $7.0 \%$ & $1.0 \%$ & $20.0 \%$ \\
\hline & \multirow{2}{*}{ Commercial Bank } & Count & 11 & 31 & 75 & 25 & 12 & 154 \\
\hline & & $\%$ of Total & $2.9 \%$ & $8.1 \%$ & $19.5 \%$ & $6.5 \%$ & $3.1 \%$ & $40.0 \%$ \\
\hline & \multirow{2}{*}{ Development Bank } & Count & 18 & 14 & 17 & 24 & 4 & 77 \\
\hline & & $\%$ of Total & $4.7 \%$ & $3.6 \%$ & $4.4 \%$ & $6.2 \%$ & $1.0 \%$ & $20.0 \%$ \\
\hline & \multirow{2}{*}{ Finance \& Cooperatives } & Count & 12 & 28 & 21 & 6 & 10 & 77 \\
\hline & & $\%$ of Total & $3.1 \%$ & $7.3 \%$ & $5.5 \%$ & $1.6 \%$ & $2.6 \%$ & $20.0 \%$ \\
\hline \multirow{2}{*}{\multicolumn{2}{|c|}{ Total }} & Count & 47 & 89 & 137 & 82 & 30 & 385 \\
\hline & & $\%$ of Total & $12.2 \%$ & $23.1 \%$ & $35.6 \%$ & $21.3 \%$ & $7.8 \%$ & $100.0 \%$ \\
\hline \multicolumn{9}{|c|}{ Chi-Square Tests } \\
\hline \multirow{2}{*}{\multicolumn{2}{|c|}{ Pearson Chi-Square }} & \multicolumn{2}{|l|}{ Value } & \multicolumn{2}{|l|}{ df } & \multicolumn{3}{|c|}{ Asymp. Sig. (2-sided) } \\
\hline & & \multicolumn{2}{|l|}{$56.619^{\mathrm{a}}$} & \multicolumn{2}{|l|}{12} & \multicolumn{3}{|c|}{.000} \\
\hline
\end{tabular}

As illustrated in table 12, significant number of respondents(23.1 percent have chosen "disagree" and 12.2 "strogly disagree") refused this statement with the view that knowledge management is very important emerging discipline rather than a normal management trend or fad. Still, there are many respondents (35.6 percent) neutral towards this saying and some of the respondents () agree with this statement and believe that it is nothing special but a management trend or fad.

The statistical analysis of Chi-Square test found the significant association among the four different financial institutions regarding the response on $\mathrm{KM}$ is nothing but a management trend or fad because the $\mathrm{P}=.000$ which is less than .05 significant level.

\section{Descriptive Statistics of Personal Awareness}

In addition to frequency analysis, the descriptive analysis regarding each question with mean and standard deviation is illustrated in table 13. For instance, the seventh statement (It is something that could be beneficial for the organization) obtained the highest mean of 4.20 since all respondents agreed firmly with this statement and the last statement (KM is nothing but a management trend or fad) obtained the lowest mean of 2.89 since most of the respondents disagreed firmly with this statement.

Table 13: Descriptive Statistics of Personal Awareness

\begin{tabular}{|c|c|c|c|}
\hline Personal Awareness & $\mathrm{N}$ & Mean & $\begin{array}{l}\text { Std. } \\
\text { Deviation }\end{array}$ \\
\hline $\mathrm{KM}$ is a process of creation, assimilation, retention and utilization of knowledge. & 385 & 4.05 & .843 \\
\hline $\mathrm{KM}$ is the management of information, knowledge and experience. & 385 & 4.06 & .798 \\
\hline It is something already doing but not under the same name. & 385 & 3.55 & .934 \\
\hline $\mathrm{KM}$ is a theory developed by an academician. & 385 & 3.39 & .987 \\
\hline It is strategic part of the business. & 385 & 3.97 & .773 \\
\hline Knowledge Management is a new marketing strategy. & 385 & 3.77 & 1.002 \\
\hline
\end{tabular}




\begin{tabular}{|l|l|l|l|}
\hline It is something that could be beneficial for the organization. & 385 & 4.20 & .742 \\
\hline KM is a type of process-improvement method. & 385 & 3.86 & .867 \\
\hline KM is a training program that all managers must participate & 385 & 3.87 & 1.048 \\
\hline Knowledge Management is all about the utilization of ICT. & 385 & 3.37 & .932 \\
\hline KM is nothing but a management trend or fad. & 385 & 2.89 & 1.112 \\
\hline
\end{tabular}

\section{DISCUSSION}

This study concluded that the level of KM awareness amongst Nepalese Banking and financial institutions is medium in which some companies understand the principles of KM but they observe many difficulties in pursuing a KM approach. We could relate the less awareness of knowledge management, training \& education with resource availability in Nepalese organizations. Most of the institutions are having characteristics of simple and flat organizational structure, limited human and financial resources. Therefore, they are not fully aware of knowledge resource to be used in their companies.

A similar type of study was conducted by Naser Valaei and Kamarulzaman Ab. Aziz who found that 50.8 percent have chosen "agree" and 12.7 percent for "totally agree". 36.5 percent have chosen "somehow agree" on the response of 'KM is a process of creating knowledge' as asked in the statement regarding awareness for their study (Valaei \& Aziz, 2012). The level of agreement is found similar because in this study also more than 80 percent agreed on it.

The results above could be compared closely to the Valmohammadi's study which is measuring the importance of awareness and success factors of KM in Iranian SMEs (Valmohammadi, 2010). In his study, Management Leadership and Support is considered as the most critical factor in Iranian SMEs, while Organizational Culture is seen as the second most important.

Abhilasha Singh and Ebrahim Soltani (2010), in their research on 'Knowledge Management Practices in Indian Information Technology companies', investigate the degree of awareness of KM principles and practices in Indian Information Technology companies. The research study shows that though people are aware of the importance of documentation, still a lot needs to be done in this field. Further the study also showed through the Knowledge Management Index, that awareness of Intellectual Property in IT companies was too low, but the same was high for Information Technology per se. This study partially supports findings made by Singh and Soltani.

The result of this study contradicts with the result of study conducted by Muhamad Prabu Wibowo in small and medium enterprises (SMEs) in Technoparks of Turkey which found that most of the employees of surveyed SMEs are aware of the best practices of KM and some of aspects in KM Awareness and Maturity Levels are affected by the size, age, annual revenue, location, sector, and industry of the company. Malhotra (2003) advocates strongly the need to develop a culture, where learning, sharing, and creating knowledge is present at all levels. He predicts that this will be a sign of successful firms of future. If somebody is aware of such culture, the employees will be hired with an urge for intellectual curiosity. As found in this study, he also reveals that in order to succeed one should develop a learning culture, which will be quick to adopt change.

A dissimilar approach of KM awareness and adoption from this study was presented by M. P. Mughal \& B. Ahmad in the Oil and Gas Automation industry in Pakistan. This study investigates awareness and adoption of KM within Oil \& Gas automation sector corporations having some presence in Pakistan. Both end users and service providers with in the sectors are sought their opinion regarding adoption and awareness of the $\mathrm{KM}$ in the industry where this study found significant differences between service providers and end users with regard to the awareness of the KM and also regarding the implementation of KM in oil \& gas automation 
industry. They also provide evidence that awareness about benefits of KM do not lead towards systematic implementation of KM and points out that there is no one size fit for all solution of KM implementation.

Another close comparison could be made to Bozbura's study, which is measuring the KM practices in Turkish SMEs (Bozbura, 2007). However, that measurement is having different variables, where the exact comparison is difficult to do. In overall, most of researched Turkish SMEs in Bozbura's study are having close to the midpoint average of the related aspects in the KM awareness. The results shows that there is increasing of the awareness of KM related aspects in Turkish SMEs. The researched manufacturing Turkish SMEs in Bozbura's study think that Policies and Strategies of KM are the most, but the effect of organizational culture is the least important. Moreover, our results for Nepalese financial institutions are dissimilar to those of Salojarvi, et.al. in Finland, where there is high awareness of KM (Salojarvi, Furu, \& Sveiby, 2005).

\section{CONCLUSION}

This study investigates the level of KM awareness amongst Nepalese financial institutions. Employees of various level and rank structure were asked eleven questions about their understanding of KM. KM awareness is not new amongst Nepalese bankers and finance sector people, considering the fact that principles of KM have been knowingly/unknowingly practiced by these organizations over and over. Nowadays, the major differences of $\mathrm{KM}$ are the changed environment as well as the technological advancements and tools. Regarding KM understanding and perceptions, based on the result of data analysis, most respondents agree that Knowledge Management could be beneficial for organization. They also concur with the statements that KM is a process of creation, assimilation, retention and utilization of knowledge, $\mathrm{KM}$ is the management of information, knowledge and experience accessible to a company, $\mathrm{KM}$ is a strategic part of business and $\mathrm{KM}$ is a type of process-improvement method. In addition, they opined differently with mixed responses for other statements but they disagreed that $\mathrm{KM}$ is a management fad or theory developed by an academician. Therefore, it can be concluded that the level of KM awareness amongst Nepalese Banking and financial institutions is medium in which some companies understand the principles of KM but they observe many difficulties in pursuing a KM approach. Based on the findings in the study, there is still lacking of knowledge management implementation and a lack of clear understanding of knowledge management itself. This research indicates that there is some form of knowledge but due to the lack of understanding and knowledge about knowledge it is not utilized properly. Awareness if given to the management and employees not only will improve their performance but also the productivity of organization, which could lead to a competitive advantage.

\section{REFERENCES}

Bixler, C.H. (2005). Developing a Foundation for a Successful Knowledge Management System. In M. Stankoshy. (Ed.).Creating the Discipline of Knowledge Management: The Latest in University Research (pp.51-65).Amsterdam, Boston: Elsevier Butterworth-Heinemann.

Bozbura, F. T. (2007). Knowledge Management Practices in Turkish SMEs. Journal of Enterprise Information, 20(2), 209-221.

Carlisle, Y. (2002), Strategic thinking and knowledge management, in Little, S., Quintas, P., Ray, T. (Eds.), Managing knowledge - An essential reader; pp. 122-138; London: The Open University \& SAGE Publications Ltd.

Frappaolo, C. (2002). Knowledge Management. Oxford: Capstone Publishing Ltd. 
ISSN: 2362-1303 (Paper) | eISSN: 2362-1311(Online)

JOURNAL OF ADVANCED ACADEMIC RESEARCH (JAAR)

October 2016

Gandhi, S. 2004, "Knowledge management and reference services", The Journal of Academic Librarianship, vol. 30, no. 5, pp. 368-381.

Lyons, K.L. (2000), Using patterns to capture tacit knowledge and enhance knowledge transfer in virtual teams, in Malhotra, Y. (Ed.), Knowledge management and virtual organizations; pp. 124143; Hershey: Idea Group Publishing.

Malhotra Y (2003). Is Knowledge The Ultimate Competitive Advantage? An Interview of Dr. Yogesh Malhotra, Bus. Manage. Asia, September, pp. 66-69

Salojarvi, S., Furu, P., \& Sveiby, K.-E. (2005). Knowledge Management and Growth in Finnish SMEs. Journal of Knowledge Management, 9(2), 103-122.

Tsoukas, H. \&Vladimirou, E. 2001, "What is organizational knowledge?",Journal of Management Studies, vol. 38, no. 7, pp. 973-993.

Valaei, N., \& Aziz, K. A. (2012). Awareness: A Study of Knowledge Management Adoption amongst Iranian SMEs. Journal of Organizational Knowledge Management , 1-14

Valmohammadi, C. (2010). Identification and Prioritization of Critical Success Factors of Knowledge Management in Iranian SMES: An Experts' View. African Journal of Business Management, 4(6), 915-924.

Vorbeck, J., Heisig, P., Martin, A., Schutt, P. (2001), Knowledge Management in a global company - IBM global services, in Mertins, K., Heisig, P., Vorbeck, J. (Eds), Knowledge Management - Best practices in Europe; pp. 174-185; Berlin: Springer-Verlag.

Zack, M.H. 1999, "Managing codified knowledge", Sloan Management review, vol. 40, no. 4, pp. 45-58. 